\title{
Kidney Bean Yoghurt is Effective to Improve Immune System and Sleep Quality Among Elderly in Yogyakarta
}

\author{
Natalia Desy Putriningtyas ${ }^{1 *}$, Ari Tri Astuti ${ }^{2}$ \\ ${ }^{1}$ Program Study of Nutrition, Department of Public Health Science, Faculty of Sport Science, \\ Universitas Negeri Semarang, Semarang 50229, Indonesia \\ ${ }^{2}$ Department of Nutrition, Faculty of Health Science, Universitas Respati Yogyakarta \\ Sleman 55282, Indonesia
}

\begin{abstract}
This study aimed to assess the effect of kidney bean yoghurt on the immune system and sleep quality in healthy elderly subjects in Yogyakarta. The study included 17 healthy elderly aged 60-81 years. The study design was a quasi-experimental, before and after design conducted at the Abiyoso Institutional Care for elderly in Yogyakarta from April to May 2018. The subjects were given $200 \mathrm{ml}$ kidney bean yoghurt everyday for 14 days. The immune system status was measured by lymphocyte count and the sleep quality was measured by the PSQI with higher scores in dicating worse sleep quality. Paired t-test was used for data analysis. Lymphocyte count after intervention (28.89 \pm 7.09$)$ was higher than before intervention $(25.96 \pm 7.41)$, and it was statistically significant $(p=0.006)$. The sleep quality index after the intervention $(4.88 \pm 1.83)$ was lower than before intervention $(8.06 \pm 3.09)$ and the difference was statistically significant $(\mathrm{p}=0.001)$. This intervention study indicates that kidney bean yoghurt significantly improves both immune systems and sleeps quality among our elderly subjects.
\end{abstract}

Keywords: elderly, kidney bean, lymphocyte, sleep quality, yoghurt

\section{INTRODUCTION}

The increasing number of elderly is one of a success indicator as well as a challenge in development. WHO reported that the global life expectancy in 2000 to 2005 was 66.4 years and will increase to 77.6 years in the year 2045 to 2050. The Central Bureau of Statistics reported that Indonesian life expectancy has also been increasing overtime, it was 64.5 years in 2000 and increased to 69.43 years in 2010 and became 69.65 in 2011 (BPS 2012). The rise in elderly population in Indonesia is predicted to be higher than its neighboring countries in Asia. Yogyakarta is a province with the highest percentages of the elderly population with the proportion of $13.04 \%$ (Dinkes DIY 2013; BPS 2012).

Aging is related to alteration in immune function, intestinal microbiota composition, and decrease in health-related quality of life like quality of sleep. In the elderly, about $20 \%$ who responded to the National Sleep Foundation (2003) poll indicated that they took something to aid sleep at least a few nights per week. About $11 \%$ reported taking a prescription medication, $6 \%$ used over-the-counter medications, and $6 \%$ used alcohol to help them sleep.
Elderly are susceptible to infections and gastrointestinal problems because of various kinds of risk factors including their slow immune response, decreased organ function, malnutrition, immunity, physical activity, and the presence of comorbidity (Guillemard 2010; Fatmah 2010; Darmojo 2010). Lymphocytes are one of the main components of the immune system which recognize and eliminate virus-infected cells (Nugroho 2008). Elderly hardly produce lymphocytes for the immune system, and the infection defense cells produced are slower and less effective than that of young adult groups.

Nutritional intake can improve the immune system and sleep quality. Protein, vitamin A, vitamin $\mathrm{C}$, vitamin $\mathrm{E}$, and antioxidant are a vital nutrient to maintain the immune system as well as sleep quality in elderly. These vitamins can boost immunity and functioned as lymphocytes protective antioxidant. In addition, consumption of antioxidant and polyphenol compound including isoflavone can protect tissues against free radicals and lipid peroxidation, as well as an anti-inflammatory (Jian Liu et al. 2014). Isoflavone is one of flavonoid compound found in legumes like the kidney bean (Phaseolus vulgaris) (Kwon et al. 2009).

\footnotetext{
"Corresponding Author: tel: +6285640885101, email: nataliadesy@mail.unnes.ac.id
} 
The body also needs micronutrient such as iron and zinc to enhance immunity and sleep quality (Bengtson et al. 2009). Extracellular zinc has the potential to interact and modulate many different synaptic targets, including Glutamate and $\gamma$-Aminobutyric Acid (GABA) receptors. Feeding the mice with zinc-containing yeast extract at the onset of the dark phase resulted in a drastic reduction of locomotor activity and increased the total amount of Non-Rapid Eye Movement (NREM) (Cherasse et al. 2015). NREM sleep is characterized by slow but relatively high amplitude oscillations (Cherasse \& Urade 2017). The kidney beans contain in abundance of these minerals.

The physiological function of elderly will naturally decrease, and so will the intestinal motility. Elderly are encouraged to overcome it by consuming specific food that can reduce or even eliminate this problem (Nugroho 2008; Darmojo 2010; Hadisaputro \& Wibisono 2010). Kidney bean yoghurt is a product that contain both the benefits of kidney bean and lactic acid bacteria. The lactic acid bacteria act as intestinal micro flora and helps the digestive process. Thus, this study aimed to assess the effect of kidney bean yoghurt on the immune system and sleep quality among the elderly in Yogyakarta.

\section{METHODS}

\section{Design, location, and time}

The study design was a quasi-experimental before and after with no control, conducted at Abiyoso Institutional Care for Older Person, Yogyakarta for two months from April to May 2018.

\section{Sampling}

The sample size used the average mean formula, resulting in sample size of 17 elderlies. The total elderly population in the care facility was 126 elderlies. The study subjects were chosen based on the inclusion and exclusion criteria to meet the quota of 17 subjects. The inclusion criteria were aged $>60$ years that categorised as elderly by WHO (2018), willing to participate in the research by signing informed consent, non-smokers, and have been living at the study site for at least three months. Exclusion criteria were undergoing treatment during the study and taking immunosuppressant medications such as cylosporin, glucocorticoids (corticosteroids), hydroxychloroquine in the past month.

\section{Data collection}

The intervention was daily intake of kidney bean yoghurt. The yoghurt made from kidney beans, skim milk, sucrose, lactic acid bacteria, consist of Lactobacillus bulgaricus and Streptococcus thermophilus, with a comparison of $50 \%: 100 \%: 20 \%: 10 \%$ respectively. Kidney bean yoghurt was produced from the boiled skim milk.

First, successive inoculations of the starter cultures tend to upset the balance between the $L$. bulgaricus and S. thermophilus. Second, the low incubation temperature (ambient as compared with the optimum temperature of $37-42^{\circ} \mathrm{C}$ ). The starter, which was obtained from starter banks, was propagated in rotation and inoculated into the skim milk under aseptic conditions and mixed with kidney bean porridge and sucrose. The temperature was accurately controlled (37$42^{\circ} \mathrm{C}$ ) during six to seven hours. The yoghurt was cooled very quickly when the desired acidity is reached (Putriningtyas 2017). The subjects consumed $200 \mathrm{ml}$ of this kidney bean yoghurt per day for 14 days.

The dependent variables were lymphocyte count and sleep quality. The lymphocytes count were measured through complete blood test using auto hematology analyzer method in Parahita Laboratory. Peripheral blood samples were obtained by venipuncture from subjects before and after study. For each subject, $4 \mathrm{ml}$ of blood was collected.

The sleep quality was measured using the Pittsburgh Sleep Quality Index (PSQI) questionnaire which includes sleep quality, sleep duration, sleep latency, sleep habits efficiency, sleep disturbance, use of drugs, and daytime dysfunction. The food intake data was obtained through 24-hours recall and leftover food observation. Diet records were kept for three days a week and two representative days were chosen for nutrient analysis by Nutrisurvey.

Subject selection, pre/post sleep quality measurement, and blood sampling was conducted in Abiyoso Institutional Care for Older Person, Yogyakarta; kidney bean yoghurt making and preparation were done in Dietetics and Culinary Laboratory Respati University, Yogyakarta; kidney bean yoghurt culture and starter were made in Microbiology Laboratory of Gajah Mada University. The study protocol was approved by The Respati University, Yogyakarta Institutional Review Boards with number 039.2/UNRIYO/ $\mathrm{PL} / \mathrm{III} / 2018$. 


\section{Data analysis}

Statistical analyses were performed using SPSS. Subjects characteristics were presented in descriptive statistics. Inferential statistics were conducted on lymphocytes count and the scores of sleep quality. Data were reported as means \pm standard deviation. Data normality was tested using the shapiro wilk test. The cut off value of $p>0.05$ indicated a normal and homogeneity of variance. Because the lymphocytes count and the scores for sleep quality were likely to be normally distributed, we used parametric tests for the analyses. The cut off value of $\mathrm{p}<0.05$ indicated a statistically significant difference. Respondents were asked for approval, and all information and data in this study were kept confidential and only used for scientific purposes.

\section{RESULTS AND DISCUSSION}

The mean age of the subjects was $72.29 \pm 6.29$ years old and Body Mass Index (BMI) was $20.19 \pm 3.31 \mathrm{~kg} / \mathrm{m}^{2}$, indicating good nutritional status. The statistical analysis result of age, weight, BMI, lymphocytes level, and sleep quality shows the $p>0.05$. It indicates that the subjects were from a homogeneous population. The characteristics are presented in Table 1 .

Food intake before intervention can be seen in Table 2. The Saphiro Wilk normality test for intake of energy, protein, fat, carbohydrate, vitamin A, Vitamin C, Vitamin E, and zinc showed $p>0.05$, which means that the subjects were at the same level of homogenity. Almost all of the elderly living in the nursing home did not buy food from outside and only consume food provided by the institution.

Protein plays an important role in the synthesis of hormones, enzymes, and immune substance which are parts of the body immune system against disease. Inadequate consumption of protein and amino acids also affect immune status as it is associated with damage to the number and function of cellular immunity and decrease in antibody response (Fatmah 2010).

In addition, vitamin $\mathrm{A}, \mathrm{C}, \mathrm{E}$, and $\mathrm{Zn}$ also pivotal in the regulations of the immune system. The lack of these nutrients will suppress the immune system and results in the occurrence of infection (Mora et al. 2008; Makino et al. 2010). Vitamin A have role in a non-specific immunity response through the maturation process of $\mathrm{T}$ lymphocytes cells and stimulates the cells to fight foreign antigen, help the mucous membranes including the lungs from invading microorganism, produce mucous as specific antibodies such as leukocytes, water, epithelium, and organic salt. Retinoic acid increases cytotoxicity and $\mathrm{T}$ lymphocyte cell proliferation (Mora et al. 2008). Research by Ravagglia et al. (2000) stated that vitamin A affects the number and function of NK cells in the elderly. While, vitamin E plays a role in enhancing immunity as an antioxidant that protects lymphocytes. Vitamin E deficiency will decreases lymphocyte proliferation, phagocyte function, and tumor resistance.

Vitamin C supplementation is known to enhance the immune system such as antimicrobial and natural killer cell activity, lymphocytes proliferation, chemo-taxis, and delayed type hypersensitivity. Vitamin $\mathrm{C}$ maintains cell integrity and protects it against reactive oxygen during an inflammatory response. Vitamin $\mathrm{C}$ increase phagocyte activity and tumor resistance, as well as increases interferon levels, lymphocytes, and macrophages activity, also improves migration and mobility of leukocytes from a viral infection like influenza (Fatmah 2010).

Zinc is important in normal development and function of immune cells, neutrophils, and natural killer cells. Macrophages are also affected

Table 1. Characteristics of the elderly before intervention

\begin{tabular}{lcc}
\hline \multicolumn{1}{c}{ Characteristics } & Mean \pm SD & $\mathrm{p}^{*}$ \\
\hline Age (years) & $72.29 \pm 6.29$ & 0.482 \\
Weight $(\mathrm{kg})$ & $51.92 \pm 8.64$ & 0.890 \\
BMI $\left(\mathrm{kg} / \mathrm{m}^{2}\right)$ & $20.19 \pm 3.31$ & 0.143 \\
Lymphocyte level (\%) & $25.96 \pm 7.41$ & 0.983 \\
Sleep quality & $8.06 \pm 3.09$ & 0.180 \\
\hline *Saphiro Wilk normality $\begin{array}{c}\text { test significant at } \\
\text { SD: Standard Deviation; BMI: Body Mass Index }\end{array}$ & $<0.005$;
\end{tabular}

Table 2. Food intake before intervention

\begin{tabular}{lcc}
\hline \multicolumn{1}{c}{ Characteristics } & Mean \pm SD & $\mathrm{p}^{*}$ \\
\hline Energy $(\mathrm{kcal})$ & $1860.72 \pm 379.88$ & 0.698 \\
Protein $(\mathrm{g})$ & $52.52 \pm 10.22$ & 0.967 \\
Fat $(\mathrm{g})$ & $65.75 \pm 15.58$ & 0.527 \\
Carbohydrate $(\mathrm{kcal})$ & $269.10 \pm 62.06$ & 0.698 \\
Vitamin A $(\mu \mathrm{g})$ & $1553.63 \pm 380.77$ & 0.863 \\
Vitamin C $(\mathrm{mg})$ & $36.35 \pm 14.93$ & 0.002 \\
Vitamin E $(\mathrm{mg})$ & $3.06 \pm 0.63$ & 0.881 \\
Zinc $(\mathrm{mg})$ & $6.86 \pm 1.30$ & 0.979 \\
\hline
\end{tabular}

*Saphiro Wilk normality test significant at $<0.005$; SD: Standard Deviation 
by zinc deficiency. Zinc deficiency will result in poor growth and function of $\mathrm{T}$ and $\mathrm{B}$ lymphocytes. Zinc, as an antioxidant, also protects the body from free radicals (Fatmah 2006). Sari stated that there is no significant relationship between zinc level and CD4+ amount, but zinc sulfate supplementation could increase CD4+ amount in eleven healthy elderly (36\%) (Sari et al. 2009).

Table 3 shows the lymphocytes count and the sleep quality score of the subjects during the study. The lymphocyte is one of the biochemical markers commonly observed in immunity. The result of 14 days consumption of $200 \mathrm{ml} /$ day kidney bean yoghurt showed that the mean lymphocyte count in before and after intervention were $25.96 \pm 7.41 \%$ and $28.89 \pm 7.09 \%$ respectively. Paired t-test result showed that there is a significant effect of kidney bean yoghurt on elderly lymphocyte count after intervention $(\mathrm{p}=0.006)$.

In addition to the antioxidant content of kidney bean, the reason for the increase in lymphocyte count was thought due to the fact that the product was in the form of yoghurt. Yoghurt is rich in probiotics, thus the consumption of kidney bean yoghurt derived from Lactobacillus bulgaricus and Streptococcus thermophilus bacteria for 14 days showed an increase in lymphocyte count in the elderly subjects. This research is in line with Wahyuningsih et al. (2014) that using yoghurt derived from $L$. helveticus Rosell $^{\circledR}-52$ and $L$. rhamnosus Rosell ${ }^{\circledR}-11$.

Probiotics consumption provides great benefits for subjects with declined immunity, as in the elderly. Probiotics stimulate immunity by suppressing the growth of disease-causing bacteria (Gill et al. 2001). This study is in line with research by Forssten et al. (2011) which administered a $100 \mathrm{ml}$ of probiotic milk with $L$. paracasei Lpc-37 for four weeks in 40 elderlies. It stated that probiotic milk with $L$. paracasei Lpc-37 significantly improved the natural killer (NK) cells activity altough the difference was significant compared to the placebo group. Regular consumption of probiotics improves non-specific immune defense. Probiotics from L. casei and L. bulgaricus species increased macrophage production and activate phagocytes in both human and experimental animal.

Phagocytosis process is the initial response of the body's defense system before the body forms antibodies. It will eliminate toxic agents that enter the body. Elderly may suffer from an immunosenescence, a condition where there is a change in the elderly immune response (Candore et al. 2008). Immune response change in the elderly includes decreased activity of NK cells (Mocchegiani et al. 2009). The cytotoxic activity of NK cells is important in fighting viruses and cancer cell response so that the decrease in NK cell activity may explains the increased incidence of infection in the elderly (Kazue et al. 2000).

Human lymphocyte tissue culture of people who consume drinks containing L. bulgaricus and $L$. thermophilus regularly, has a greater amount of IFN- $\gamma$. Lactobacillus and Bifidobacterium, the largest colony in the gastrointestinal tract are capable of modifying reactions associated with allergies and inflammation. The L. Casey induces the formation of IL-2 and TGF, while $L$. reuteri induces IL-10 that down-regulates the mechanism (inhibit IL-4 and IL-5 production) to avoid excessive burden on cytokine (Fukushima et al. 2007). Lactobacillus and Bifidobacterium are also dominant bacteria in the small intestine. These bacteria help the food digestion process while some also function as antimicrobial such as the L. rhamnosus GG and helps increase body resistance to infectious disease, especially to those which occur in the intestine (Widiyaningsih 2011). In addition to the role of gut bacteria, the lymphocytes activities and the immunoglobulin production were also affected by various other factors, such as nutrition, physical activity, illness, emotion, age, gender, circadian rhythm, body temperature, drugs, and quality of sleep (Herich \& Levkut 2002).

Sleep latency is the length of time needed by the elderly to fall asleep. Elderly living in this nursing house need around 16-30 minutes to fall asleep. Studies have found that for older adults living in nursing homes, not a single hour in a 24 hour day was spent fully awake or fully asleep (Cooke \& Ancoli-Israel 2011). Unhealthy

Table 3. Immunity and sleep quality of the erderly during the study

\begin{tabular}{lcccc}
\hline & Pre & Post & $\Delta$ & $\mathrm{p}^{*}$ \\
\hline Lymphocytes count (\%) & $25.96 \pm 7.41$ & $28.89 \pm 7.09$ & $2.94 \pm 3.79$ & 0.006 \\
Sleep quality & $8.06 \pm 3.09$ & $4.88 \pm 1.83$ & $-3.18 \pm 2.51$ & 0.001 \\
\hline
\end{tabular}

$\Delta$ : difference in immunity levels before and after 14 days of intervention, *paired t-test, significant 
environment, noise, light exposure and pre-bed habits such as eating, drinking, and smoking will reduce sleep duration and lead to an increase in sleep latency (Carole 2008; Cooke \& AncoliIsrael 2011). Sleep quality parameter in PSQI included seven components. These components are subjective sleep quality, sleep latency, sleep duration, sleep efficiency, sleep disturbance, sleeping medication usage, and daytime dysfunction. Sleep quality can be influenced by several factors such as environment, physical illness, fatigue, life style, emotional stress, diet, smoking, and medication (Nugroho 2008).

Table 4 shows that the sleep quality of the elderly had improved after intervention. The average of sleep quality score before and after intervention were $8.06 \pm 3.09$ and $4.88 \pm 1.83$ respectively with $\mathrm{p}=0.001$. It can be concluded that there was a significant effect on the sleep quality of the elderly before and after consuming kidney bean yoghurt for 14 days. The frequency distribution of the subjects based on the PSQI component before and after the intervention can be seen in Table 4. Overall, the elderly have good sleep quality.

Sleep duration is the actual range of sleep time. The National Sleep Foundation placed more than 10 hours in a not recommended category for adult aged 26-6 and more than 9 hours as not recommended for adults 65 and older (Lauderdale

Table 4. Frequency distribution of the elderly based on PSQI

\begin{tabular}{|c|c|c|c|c|}
\hline PSQI Component & Score & Interpretation & $\mathrm{n}(\%)$ before & $\mathrm{n}(\%)$ after \\
\hline \multirow[t]{4}{*}{ Subjective sleep quality } & 0 & Very good & $1(5.9 \%)$ & $7(41.2 \%)$ \\
\hline & 1 & Good & $7(41.2 \%)$ & $9(52.9 \%)$ \\
\hline & 2 & $\mathrm{Bad}$ & $9(52.9 \%)$ & $1(5.9 \%)$ \\
\hline & 3 & Very bad & $0(0 \%)$ & $0(0 \%)$ \\
\hline \multirow[t]{4}{*}{ Sleep latency } & 0 & $\leq 15$ minutes & $0(0 \%)$ & $7(41.2 \%)$ \\
\hline & 1 & 16-30 minutes & $12(70.6 \%)$ & $9(52.9 \%)$ \\
\hline & 2 & $31-60$ minutes & $3(17.6 \%)$ & $1(5.9 \%)$ \\
\hline & 3 & $>60$ minutes & $2(11.8 \%)$ & $0(0 \%)$ \\
\hline \multirow[t]{4}{*}{ Sleep duration } & 0 & $>7$ hours & $2(11.8 \%)$ & $5(29.4 \%)$ \\
\hline & 1 & 6-7 hours & $7(41.2 \%)$ & $11(64.7 \%)$ \\
\hline & 2 & 5-6 hours & $6(35.3 \%)$ & $1(5.0 \%)$ \\
\hline & 3 & $<5$ hours & $2(11.8 \%)$ & $0(0 \%)$ \\
\hline \multirow[t]{4}{*}{ Sleep habit efficiency } & $0(\geq 85 \%)$ & Very efficient & $6(35.3 \%)$ & $14(82.4 \%)$ \\
\hline & $1(75-84 \%)$ & Fairly efficient & $8(47.1 \%)$ & $3(17.6 \%)$ \\
\hline & $2(65-74 \%)$ & Inefficient & $2(11.8 \%)$ & $0(0 \%)$ \\
\hline & $3(<65 \%)$ & Very inefficient & $1(5.9 \%)$ & $0(0 \%)$ \\
\hline \multirow[t]{4}{*}{ Sleep disturbance } & $0(0)$ & Never & $0(0 \%)$ & $2(11.8 \%)$ \\
\hline & $1(1-9)$ & $<1 \mathrm{x} /$ week & $11(64.7 \%)$ & $14(82.4 \%)$ \\
\hline & $2(10-18)$ & $1-2 \mathrm{x} /$ week & $6(35.3 \%)$ & $1(5.9 \%)$ \\
\hline & $3(19-27)$ & $\geq 3 \mathrm{x} /$ week & $0(0 \%)$ & $0(0 \%)$ \\
\hline \multirow{4}{*}{$\begin{array}{l}\text { Use of sleeping } \\
\text { medication }\end{array}$} & 0 & Never & $15(88.2 \%)$ & $16(94.1 \%)$ \\
\hline & 1 & $<1 \mathrm{x} /$ week & $1(5.9 \%)$ & $0(0 \%)$ \\
\hline & 2 & $1-2 \mathrm{x} /$ week & $1(5.9 \%)$ & $0(0 \%)$ \\
\hline & 3 & $\geq 3 \mathrm{x} /$ week & $0(0 \%)$ & $1(5.9 \%)$ \\
\hline \multirow[t]{4}{*}{ Daytime dysfunction } & 0 & 0 & $1(5.9 \%)$ & $3(17.6 \%)$ \\
\hline & 1 & $1-2$ & $10(58.8 \%)$ & $3(17.6 \%)$ \\
\hline & 2 & $3-4$ & $4(23.5 \%)$ & $11(64.7 \%)$ \\
\hline & 3 & $5-6$ & $2(11.8 \%)$ & $0(0 \%)$ \\
\hline
\end{tabular}

Pittsburgh Sleep Quality Index 
et al. 2016). Post intervention data showed that most of elderly in this nursing home have six to seven hours of sleep per day, thus showed a normal needs and pattern of sleep for elderly due to decrease in the $1^{\text {st }}$ and $2^{\text {nd }}$ phase in NREM, and a decrease or disappearance of stage $3^{\text {rd }}$ and $4^{\text {th }}$ delta wave activity. This makes the sleep duration in elderly shorter compared to the 8 hours normal sleep duration in adult population. Elderly who sleep more than seven hours are likely because they could adapt to the changes along the ageing process (Carole 2008; Smyth 2007; Roccichelli et al.2010). After the intervention of kidney bean yoghurt, data showed that the sleep efficiency in elderly had improved. Sleep efficiency and total sleep time are reduced with age and there are an increased number of sleep stage shift. Compared to younger adults, the elderly spend more time in bed but have deterioration in both the quality and quantity of sleep (Cooke \& Ancoli-Israel 2011)

The change in the sleep habit efficiency is caused by the change in individual sleep pattern and can also be due to a less conducive environment or other factors including diet (Carole 2008). The efficiency of sleeping habits can be measured by comparing actual sleep time to the length of time people need to stay in bed, and multiplied it with $100 \%$. The result of more than $85 \%$ means that people have an efficient sleep and less than that means inefficient sleep. Most of the elderly subjects in our study had efficient sleep time after the kidney bean yoghurt intervention.

Sleep disturbance weakens the immune system due to decreased Natural Killer Cell (NKC) which is a part of the body system. Low levels of NKC weaken immunity, resulting in susceptibility to disease (Dunhoff 1998). Components of question regarding sleep disturbance include unable to fall asleep within 30 minutes, wake up in the middle of the night or early morning, have to get up to use the bathroom, unable to breathe comfortably during sleep, cough or snore loudly during sleep, too cold or chills fever during sleep, overheats during sleep, experience nightmare, feel pain (e.g. cramps, sore, and aches). The medications used to treat these various underlying medical problems can also cause disruption in sleep. Beta blockers, bronchodilators, diuretics, decongestants as well as other cardiovascular, neurologic, psychiatric and gastrointestinal medications can all cause sleep disturbances. One way to improve sleep quality is to consume sleeping medication, it is useful to ease the sleeping process, but it made the elderly experience sleep disturbances (Roccichelli et al. 2010). Most of the elderly at Abiyoso Institutional Care for Older Person do not take any sleeping medication to overcome sleep disturbances. We found that the sleep disturbance in our study subjects in the pre intervention was worse than in the post intervention.

There were no problems in the elderly daytime activities because they have already been scheduled by the institution. Regular activities at the institution include religious activity, gymnastics, handicrafts, community service, and arts. Most of the elderly frequently woke up at night to go to the bathroom $\geq 3 \mathrm{x} /$ week. Incontinence is associated with decreased bladder muscle function due to the ageing process, so the elderly often wake up at night to urinate and difficult to go back to sleep (Nugroho 2008; Maryam et al. 2008).

Most elderly have never complained about uncomfortable breathing, coughing, feeling cold or overheat, nightmare, or pain while sleeping at night. Sleep comfort of the elderly is also affected by comfortable room in the nursing house. The nursing house consists of several pavilions, each has four-five bedrooms for two people/room. Ventilation and circulation of the room are good enough with sufficient lighting, which allows the elderly to rest comfortably. In addition, kidney bean yoghurt can helped improve the sleep quality. The fermentation process of the kidney bean yoghurt can directly affect sleep and nerve activity because of the quantity and absorption of various bioactive peptides and mineral such as zinc. The bioactive peptides may be related to GABAergic or serotonergic neurons like melatonin that help regulated the body's circadian rhythm (Yamamura et al. 2009).

\section{CONCLUSION}

This relatively short-term study indicates that kidney bean yoghurt appears to improve both the immune system and sleep quality among the elderly subjects. A longer study with a control group is needed, to highlight the role of kidney beans apart from the yoghurt form, a kidney bean porridge may be developed. More spesific immunity parameters would be required such as NKC, TNF- $\alpha$, or CD4+. Side effects of consuming kidney bean yoghurt, such as bloating should be also be identified. 


\section{ACKNOWLEDGEMENT}

This study received grants from Ministry of Research, Technology, and Higher Education of Republic of Indonesia year 2017/2018. The authors has no conflict of interest.

\section{REFERENCES}

[BPS] Badan Pusat Statistik. 2012. National social and economic survey 2012. Jakarta: BPS. https://mikrodata.bps.go.id/mikrodata/ index.php/catalog/633 [Accessed 10th November 2019].

Bengtson VL, Gans D, Putney NM, Silverstein M. 2009. Handbook of Theories of Aging 2nd Edition. New York: Springer Publishing Company, LLC.

Candore G, Balistreri CR, Colonna- Romano G, Grimaldi MP, Lio D, Listi F, Scola L, Vasto S, Caruso C. 2008. Immunosenescence and anti-immunosenescence therapies: The case of probiotics. Rejuvenation Research. 11(2):425-432. https://doi.org/10.1089/rej .2008 .0662 .

Carole A. 2008. Evaluating sleep quality in older adults: the Pittsburgh sleep quality index can be used to detect sleep disturbances or deficits. Am J Nurs 108(5):42-50. doi: 10.1097/01.NAJ.0000317300.33599.63

Cherasse Y, Saito H, Nagata N, Aritake K, Lazarus M, Urade Y. 2015. Zinccontaining yeast extract promotes nonrapid eye movement sleep in mice. Mol Nutr Food Res 59(10):2087-2093. https://doi. org/10.1002/mnfr.201500082.

Cherasse Y, Urade Y. 2017. Dietary zinc acts as a sleep modulator. Int. J. Mol. Sci. 18(11):2334-2346. https://doi.org/10.3390 /ijms18112334.

Cooke JR, Ancoli- Israel S. 2011. Normal and abnormal sleep in the elderly. Handb Clin Neurol 98:653-665.

Darmojo RB. 2009. Teori Penuaan. Dalam: Martono HH, Pranarka K. Buku Ajar Boedhi Darmojo Geriatri: (Ilmu Kesehatan Usia Lanjut) 4th . Jakarta: FKUI.

[Dinkes] Dinas Kesehatan DI Yogyakarta. 2013. Profil Kesehatan Kota Yogyakarta Tahun 2013. Yogyakarta: Dinkes DIY. [Accessed on 10th May 2018].

Dunhoff C. 1998. Sleep may have negative impact on immune system. UPMC News Bureau. Available at: http://www.upmc. com.media/newsreleases/1998/pages/ sleep-may-have-negative-impact-onimmune-system.aspx.

Fatmah. 2006. Respons imunitas yang rendah pada tubuh manusia usia lanjut. Makara, Kesehatan 10(1):47-53. https://doi/org/10. 7454/msk.v10i1.169

Fatmah. 2010. Nutrition for Eldery. Jakarta: Erlangga.

Forssten SD, Salazar N, Lopez P, Nikkilä J, Ouwehand AC, PattersonA, Ruas-Madiedo P, Suarez A, Gonzalez S, Gueimonde M. 2011. Influence of a probiotik milk drink, containing Lactobacillus paracasei Lpc37 , on Immune function and gut microbiota in elderly subjects. European J Nutr Food Saf 1(3):159-172.

Fukushima Y, Miyaguchi S, Yamano T, Kaburagi T, Iino H, Ushida K, Sato K. 2007. Improvement of nutritional status and incidence of infection in hospitalized, enterally fed elderly by feeding of fermented milk containing probiotic Lactobacillus johnsonii La1 (NCC533). Br J Nutr 98(5):969-977. https://doi. org/10.1017/S0007114507764723.

Gill HS, Rutherfurd KJ, Cross ML, Gopal PK. 2001. Enhancement of immunity in the elderly by dietary supplementation with the probiotic Bifidobacterium lactis HN019. Am J Clin Nutr 74(6):833-839. https://doi. org/10.1093/ajcn/74.6.833.

Guillemard E, Tondu F, Lacoin F, Schrezenmeir J. 2010. Consumption of a fermented dairy product containing the probiotic Lactobacillus casei DN-114001 reduces the duration of respiratory infections in the elderly in a randomized controlled trial. Br J Nutr 103(1):58-68. https://doi. org/10.1017/S0007114509991395.

Hadisaputro S, Wibisono BH. 2009. Infeksi Pada Lansia. Dalam: Martono HH, Pranarka K. Buku Ajar Boedhi Darmojo: Geriatri (Ilmu Kesehatan Usia Lanjut) Edisi Ke-4. Jakarta: FKUI.

Herich R, Levkut M. 2002. Lactic acid bacteria, probiotics and immune system. Vet Med 47(6):169-180.

Liu YJ, Zhan J, Liu XL, Wang Y, Jia J, He QQ 2014. Dietary flavonoids intake and risk of type 2 diabetes: A meta-analysis of prospective cohort studies. Clin Nutr 33(1):59-63.

Kazue I, Matsuyama S, Miyake S, Suga K, Nakachi K. 2000. Natural cytotoxic activity of peripheral-blood lymphocytes 
and cancer incidence: an 11-year followup study of a general population. The Lancet 356(9244):1795-1799. https://doi. org/10.1016/S0140-6736(00)03231-1.

Kwon DY, Hong SM, Ahn IS, Kim YS, Shin DW, Park S. 2009. Kochujang, a Korean fermented red pepper plus soybean paste, improves glucose homeostasis in $90 \%$ pancreatectomized diabetic rats. Nutrition 25(7):790-799.

Lauderdale DS, Chen JH, Kurina LM, Waite LJ, Thisted RA. 2016. Sleep duration and health among older adults: Associations vary by how sleep is measured. J Epidemiol Community Health. 70(4): 361-366.

Makino S, Ikegami S, Kume A, Horiuchi H, Sasaki H, Orii N. 2010. Reducing the risk of infection in the elderly by dietary intake of yoghurt fermented with Lactobacillus delbrueckii ssp. blgaricus OLL1073R-1. Br J Nutr 104(7):998-1006. doi:10.1017/ S000711451000173X.

Maryam RS, Ekasari MF, Rosidawati, Jubaedi A, Batubara I. 2008. Mengenal Usia Lanjut dan Perawatannya. Jakarta: Salemba Medika.

Mocchegiani E, Giacconi R, Cipriano C, Malavolta M. 2009. NK and NKT cells in aging and longevity: Role of zinc and metallothioneins. J Clin Immunol 29(4):416-425.

Mora JR, Iwata M, Von Andrian UH. 2008. Vitamin effects on the immune system: Vitamins A and D take centre stage. Nat Rev Immuno 8(9):685-698.

National Sleep Foundation. 2003. Sleep in America poll. March 10, 2003.https://www. sleepfoundation.org/sites/default/files/ inline-files/2003SleepPollExecSumm.pdf. [Accessed 10th November 2019].

Nugroho W. 2008. Keperawatan Gerontik dan Geriatrik Edisi 3. Jakarta: EGC.

Putriningtyas ND dan Wahyuningsih S. 2017. Potensi yogurt kacang merah (Phaseolus vulgaris $\mathrm{L}$ ) ditinjau dari sifat organoleptik, kandungan protein, lemak dan flavonoid. Jurnal Gizi Indonesia 6(1):37-43.

Ravagglia G, Forti P, Maioli F, Bastagli L, Facchini A, Mariani E, Savarino L, Sassi S, Cucinotta D, Lenaz G. 2000. Effect of micronutrient status on natural killer cell immune function in healthy free living subjects aged $\geq 90 \mathrm{y}$. Am J Clin Nutr 71(2):590-598.

Roccichelli JT, Sanford JT, Vanewaa E. 2010. Managing sleep disorders in the elderly. Nurse Pract 35(5):30-37.

Sari YR, Juffrie M, Pramantara IDP. 2009. Pemberian seuplemen seng sulfat dan pengaruhnya terhadap kadar seng serum dan jumlah $\mathrm{CD}^{+}$pada wanita usia lanjut sehat. JGKI 5(3):101-107.

Smyth C. 2007. The pittburgh sleep quality index (PSQI). Tersedia pada: https://consultgeri. org/try-this/general-assessment/issue6.1.pdf. [Accessed 10th November 2019].

Wahyuningsih R, Darmono SS, Margawati A. 2014. Pengaruh pemberian probiotik Lactobacillus helveticus Rosell-52 dan Lactobacillus rhamnosus Rosell-11 terhadap kadar limfosit lanjut usia. Jurnal Gizi Indonesia 3(1):13-19.

[WHO] World Health Organization. 2018. Elderly population "Trends in proportion of older persons $(60+)$. South-East Asia. World Health Organization. http://www.searo. who.int/entity/health_situation_trends/ data/chi/elderly-population/en/ [Äccessed 10th November 2019].

Widiyaningsih EN. 2011. Peran probiotik untuk kesehatan. Jurnal Kesehatan 4(1):14-20.

Yamamura S, Morishima H, Kumano-go T, Suganuma N, Matsumoto $\mathrm{H}$, Adachi $\mathrm{H}$, Sigedo Y, Mikami A, Kai T, Masuyama A, et al. 2009. The effect of Lactobacillus helveticus fermented milk on sleep and health perception in elderly subject. Eur J Clin Nutr 63(1):100-103. 